\title{
TRACTION ELECTRIC DRIVE BASED ON FUEL CELL BATTERIES AND ON-BOARD INERTIAL ENERGY STORAGE FOR MULTI UNIT TRAIN
}

The aim of the work is to study the possibility and features of the use of inertial storage devices in the traction electric drive of multi unit train with a power plant based on fuel cells. Methodology. The principle of power flow control in traction electric drives in the modes of acceleration and braking of rolling stock is proposed. The mathematical model of the traction electric drive in the form of the combination of three components: the train, the traction unit and the battery of fuel cells is developed. It was used to study the operation of a traction electric drive when solving a test traction task for rolling stock. Results. It is established that the use of inertial energy storage reduces hydrogen consumption by at least $25 \%$, which increases the mileage of rolling stock between equipment by more than $30 \%$. Originality. The traction electric drive on the basis of fuel elements and the inertial energy storage for the multi unit train is offered. The work of the proposed traction electric drive in solving the test traction problem for rolling stock is investigated. Practical significance. A mathematical model of the traction electric drive has been developed. The test traction problem for rolling stock is solved. References 16, tables 4, figures 6.

Key words: traction electric drive, fuel cell, inertial storage, multi unit train.

В роботі розглянуто тяговий електропривод на основі паливних елементів та інериійного накопичувача енергії для моторвагонного рухомого складу. Запропоновано принцип керування потоками потужності у тяговому електроприводі $y$ режимах розгону та гальмування рухомого складу. Розроблено математичну модель тягового електропривода у виглядi сукупності трьох складових: поїзда, тягового блока і батареї паливних елементів. За допомогою неї досліджено роботу запропонованого тягового електроприводу при виріменні тестової тягової задачі для рухомого складу. Встановлено, щңо застосування інерційного накопичувача енергії зменшує витрати водню не мени ніж на $25 \%$, шьо забезпечує збільшення пробігу рухомого складу між екіпіруванням понад $30 \%$ Бібл. 16, табл. 4, рис. 6.

Ключові слова: тяговий електропривод, паливний елемент, інерційний накопичувач, мотор-вагонний рухомий склад.

В работе рассмотрены тяговый электропривод на основе топливных элементов и инериионного накопителя энергии для мотор-вагонного подвижного состава. Предложен принци управления потоками мощности в тяговом электроприводе 8 режимах разгона и торможения подвижного состава. Разработана математическая модель тягового электропривода в виде совокупности трех составляющих: поезда, тягового блока и батареи топливных элементов. С помощью нее исследована работа предложенного тягового электропривода при решении тестовой тяговой задачи для подвижного состава. Установлено, что при применении инериионного накопителя энергии уменьшается расход водорода не менее чем на $25 \%$, что обеспечивает увеличение пробега подвижного состава между экипировками более чем на $30 \%$. Библ. 16 , табл. 4, рис. 6.

Ключевые слова: тяговый электропривод, топливный элемент, инерционный накопитель, мотор-вагонный подвижной состав.

Introduction. Fuel cells as the basis for efficient and environmentally friendly power supply systems are currently of interest in terms of their use on rolling stock by replacing conventional diesel trains on non-electrified railway lines with multi unit «hydrogen» trains [1,2]. To date, several global manufacturers have created rolling stock using fuel cells [3]. For the first time, fuel cells on rolling stock were used on prototype trains by JR East Company and the RTRI Research Center in Japan. In the USA, fuel cells were installed on a BNSF shunting diesel locomotive for research and trial operation. After extensive testing of the «hydrogen» trains iLINT (developed by Alstom) and Mireo Plus H (developed by Siemens), these Companies have entered into contracts for the commercial supply of fuel cell trains. Spanish Companies CAF and Talgo are planning the modernization and creation of multi unit trains using fuel cells. However, the use of fuel cells on rolling stock has a number of features due to the specificity of the traction drive, which is characterized by a wide range of changes in load and rotation speed.

Analysis of literature data and problem definition. An integral part of a fuel cell power plant is an energy storage device, the use of which increases the efficiency of using fuel cells on a rolling stock. In existing projects, only lithium-ion batteries are considered as energy storage [3-5]. Inertial energy storage units remain out of sight for such trains [5]. However, despite the successes in the development of electrochemical storage devices, we consider it expedient to study and investigate all available technical solutions for energy storage devices, the use of which contributes to an increase in the energy and resource efficiency of rolling stock.

The analysis [6-9] showed that the specific weight energy indicators of capacitor, electrochemical and inertial storage devices have practically the same order of $0.02-0.08 \mathrm{MJ} / \mathrm{kg}$. As for the specific volumetric energy indicators, here inertial ones are superior to other types [6]: $25.7-151 \mathrm{MJ} / \mathrm{m}^{3}$ for inertial ones and $0.6-17.3 \mathrm{MJ} / \mathrm{m}^{3}$ for other types. The same picture is observed with weight, as well as volumetric specific power indicators: $1.29-2.5 \mathrm{~kW} / \mathrm{kg}$ and $536-4273 \mathrm{~kW} / \mathrm{m}^{3}$ for inertial ones, as well as $0.16-0.26 \mathrm{~kW} / \mathrm{kg}$ and $54-173 \mathrm{~kW} / \mathrm{m}^{3}$ for other types. Therefore, we can say that inertial energy storage devices are significantly superior to capacitor and electrochemical storage devices in terms of their specific energy and power indicators. But, unlike electrochemical

(C) V.I. Omelyanenko, Ie.S. Riabov, L.V. Overianova, H.V. Omelianenko 
storage devices, which are widely used on various vehicles and the features of their application in traction electric drives have been studied quite well, the use of inertial storage devices on vehicles is limited [9-13].

The goal of the work is a study of the possibility and peculiarities of using inertial storage devices in the traction electric drive of multi unit trains with a power plant based on fuel cells.

To achieve this goal, two tasks were solved. The first one is to create a general mathematical model of a traction electric drive of the regional multi unit train with an autonomous power source based on a battery of fuel cells and an on-board inertial energy storage device, which would link the main parameters of the power plant components with the operating properties of this drive and adequately reflect all modes of its operation. The second one is to test the created model using the example of a conceptual project of a regional train moving along a specific non-electrified section of the railway.

1. Diagram of a traction electric drive and power flows. Traction electric drive diagram shown in Fig. 1, includes the following components: a source of electrical energy, a storage device and an actuator. The source of electrical energy is represented by a hydrogen storage system (HFT), a fuel cell (FC) and a P DC-DC converter. The storage device is represented by an inertial energy accumulator FESS and an S_DC-DC converter. The actuator (DM) consists of an induction traction motor (IM), a gearbox (G) and a wheel-rail (W-R) mechanism. The output of the P_DC-DC converter and the input of the autonomous voltage inverter (TI) are connected by a DC bus, to which FESS, an auxiliary power system (AS), and a braking resistor block (BR) are connected in parallel through the corresponding semiconductor converters.

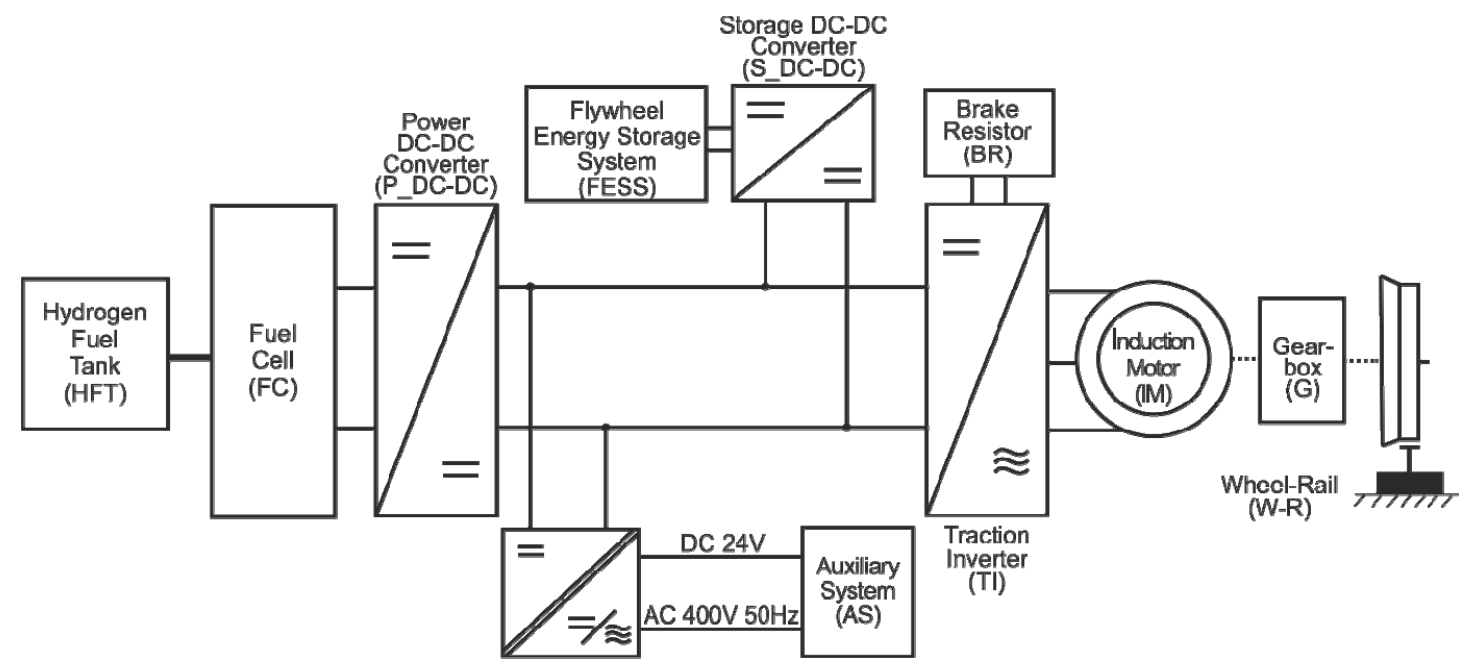

Fig. 1. Traction drive block diagram:

HFT - hydrogen storage system; FC - fuel cell battery; P_DC-DC - DC voltage converter of the fuel cell battery; FESS - energy storage; S_DC-DC - storage DC converter; AS - auxiliary power supply system; BR - block of braking resistors; TI - autonomous voltage inverter; IM - traction induction motor; $\mathrm{G}$ - gearbox; W-R - wheel-rail mechanism

The calculation diagrams of power flows between the main nodes of the traction electric drive diagram for various operating modes of the rolling stock were determined by us, based on the following assumptions.

The nominal electric power of the fuel cell battery $P_{f c}$ is determined based on the requirement to ensure the driving mode with the maximum permissible speed, as well as the operation of auxiliary devices $P_{a s}$. That is, the condition must be met

$$
P_{f c}=P_{p}+P_{a s}
$$

where $P_{p}$ is the power supplied to the traction unit.

Here, the power consumed by auxiliary devices, in any modes of movement of the rolling stock, is taken as a constant value $P_{a s}=$ const.

The value of the energy intensity and power of the storage device are taken such that they are able to provide, together with $\mathrm{FC}$, the required modes of acceleration and braking of the rolling stock. Therefore, the braking resistor link BR can be excluded from consideration.
Diagrams of power flows in the modes of braking and acceleration of the rolling stock are shown in Fig. 2. It is obvious that for the adopted scheme of the traction electric drive, the power flows are determined by the values of the currents in the corresponding branches. We will consider the processes from the standpoint of the storage device.

Braking mode.

The current $I_{c h}$ consumed by the drive in this operating mode, in accordance with the 1st Kirchhoff law

$$
I_{c h}=I_{i n v}-I_{a s}+I_{d c} \text {. }
$$

Current $I_{i n v}$ due to IM operation in generator mode:

$$
I_{\text {inv }}=\frac{P_{w r}}{U_{d c}} \eta_{\Sigma}=\frac{\sqrt{3}}{U_{d c}} U_{m} I_{m} \eta_{i n v} \cos \varphi_{m},
$$

where $\eta_{\Sigma}=\eta_{g} \eta_{m} \eta_{i n v}$ is the total efficiency of the DM link of the traction block; $\cos \varphi_{m}$ is the power factor of the IM; $\eta_{g}, \eta_{m}, \eta_{i n v}$ are the efficiencies of the gearbox, IM and TI, respectively.

Current consumed by auxiliary devices:

$$
I_{a s}=P_{a s} / U_{d c} \text {. }
$$




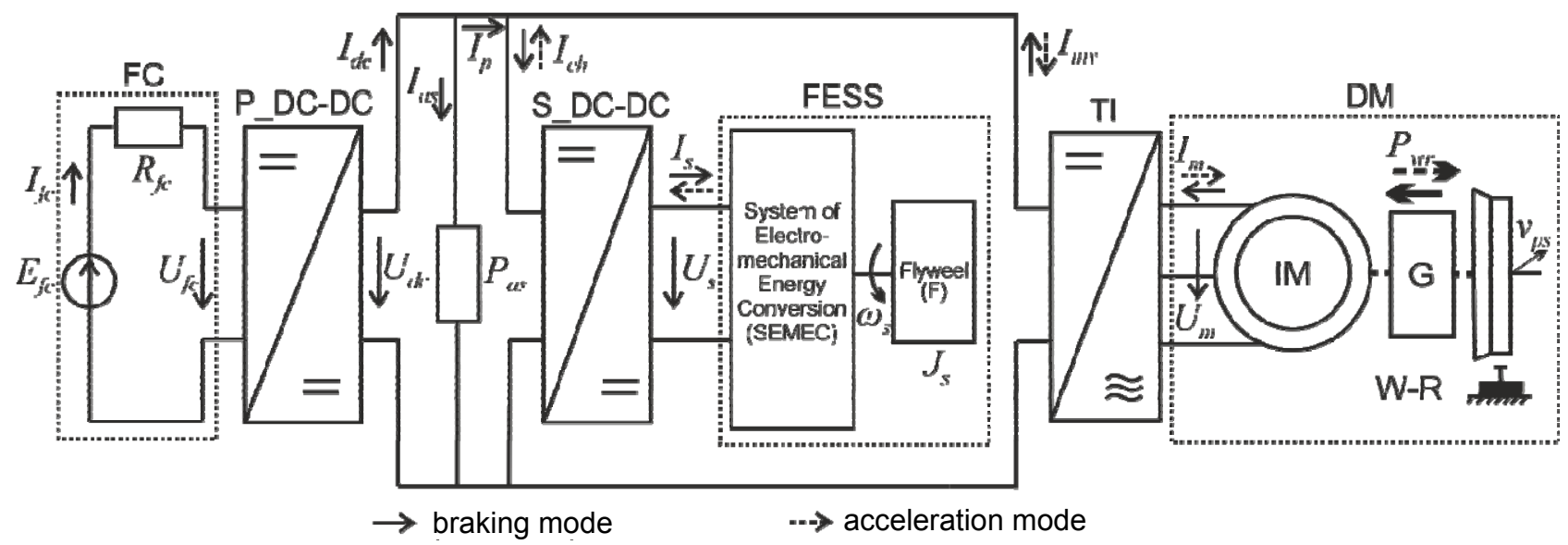

Fig. 2. Calculation diagram of the braking and acceleration modes:

$I_{f c}$ - current of the FC; $I_{d c}$ - current on the output of the P_DC-DC; $I_{p}$ - current supplied to the traction block; $I_{a s}$ - auxiliary current; $I_{c h}$ - current on the input of the S_DC-DC; $I_{s}$ - current of the FESS; $I_{i n v}$ - current of the TI; $I_{m}$ - current of the IM;

$U_{f c}, U_{d c}, U_{s}, U_{m}-\mathrm{FC}, \mathrm{DC}$ link, SEMEC and IM voltages, respectively; $E_{f c}$ - electromotive force (EMF) of the FC;

$R_{f c}-$ active resistance of the FC; $P_{w r}-$ rim power; $\omega_{s}, J_{s}$ - flywheel F speed and moment of inertia; $v_{p s}-$ train speed

FC current:

$$
I_{d c}=\frac{U_{f c} \eta_{f_{c}}}{U_{d c}} I_{f c},
$$

where $\eta_{f c}$ is the efficiency of the FC.

As a result, the power consumed by the storage device is supplied to the storage electromechanical energy conversion (SEMEC) system by current

$$
I_{c h}=\frac{\sqrt{3}}{U_{d c}} U_{m} I_{m} \eta_{i n v} \cos \varphi_{m}-\frac{P_{a s}}{U_{d c}}+\frac{U_{f_{c}} \eta_{f_{c}}}{U_{d c}} I_{f_{c}} .
$$

Based on the power balance for the storage device

$$
U_{d c} I_{c h} \eta_{s_{-} d c}=U_{s} I_{s},
$$

where $\eta_{s_{-} d c}$ is the efficiency of the P_DC-DC, and the current consumed by the SEMEC of the storage device is

$$
I_{s}=\frac{U_{d c} I_{c h} \eta_{s_{-} d c}}{U_{s}} .
$$

As a result, we get the accumulation of energy by the storage device in the process of braking of the rolling stock in the form of an increase in the rotation frequency of its flywheel

$$
\frac{d \omega_{s}}{d t}=\frac{U_{s} I_{s} \eta_{s}}{J_{s} \omega_{s}}
$$

where $\eta_{s}$ is the efficiency of the FESS.

\section{Acceleration mode.}

Here IM consumes the electricity generated by the FC minus the energy used for its own needs, as well as the energy stored by the storage device.

In this mode, the current supplied by the storage device, in accordance with the 1st Kirchhoff law, is defined as

$$
I_{c h}=I_{i n v}+I_{a s}-I_{d c} .
$$

The current consumed by the autonomous traction inverter

$$
I_{i n v}=\frac{P_{w r}}{U_{d c} \eta_{\Sigma}}=\frac{\sqrt{3}}{U_{d c} \eta_{i n v}} U_{m} I_{m} \cos \varphi_{m}
$$

Provided that the expressions for the current consumed by the auxiliary devices and generated by the FC remain the same - (4) and (5), respectively, the power generated by the SEMEC of the storage device is supplied to the DC link by current

$$
I_{c h}=\frac{\sqrt{3}}{U_{d c} \eta_{i n v}} U_{m} I_{m} \cos \varphi_{m}+\frac{P_{a s}}{U_{d c}}-\frac{U_{f_{c}} \eta_{f_{c}}}{U_{d c}} I_{f_{c}} .
$$

From the power balance for the SEMEC of the storage device in this mode

$$
U_{d c} I_{c h}=U_{s} I_{s} \eta_{s_{-} d c}
$$

we get the current supplied by the SEMEC of the storage device, in the following form

$$
I_{s}=\frac{U_{d c}}{U_{s} \eta_{s_{-} d c}} I_{c h} .
$$

The mechanical power spent on the acceleration of the train, taken from the flywheel of the storage device, is fed through the SEMEC to the S_DC-DC

$$
N=J_{s} \omega_{s} \frac{d \omega_{s}}{d t} \eta_{s}=U_{s} I_{s} .
$$

As a result, in the process of acceleration, we get a decrease in the energy stored by the flywheel due to a decrease in the frequency of its rotation.

$$
\frac{d \omega_{s}}{d t}=\frac{U_{s} I_{s}}{J_{s} \omega_{s} \eta_{s}}
$$

Thus, from the above relationships, it is obvious that with the required power on the wheel rims $P_{w r}$ and the available power of the FC $P_{f c}$, the presence of an energy storage device in the traction electric drive circuit allows organizing power flows between its components in any operating modes of the rolling stock (by analogy with those discussed above, also in the driving modes with constant speed, coasting and parking). The voltage relationships at the inputs and outputs of the power parts of the semiconductor converter circuits (P_DC-DC, S_DC-DC, TI), through which FC, FESS and DM are connected to the DC link bus act as a regulator of these flows. 


\section{Traction drive mathematical model.}

We represent the mathematical model of the considered traction drive in the form of a combination of three components: a train, a traction block, and a battery of fuel cells.

\section{Mathematical model of a train.}

The traction or braking force of the rolling stock $\pm F_{t}$ in the entire speed range is determined by the power on the rim of the wheels $P_{w r}= \pm F_{t} v_{p s}$ which is due to the total power of the traction motors on the axles of the wheelsets equipped with motors.

If we assume that a train with mass $m_{p s}$ concentrated at one point moves along a track of length $s$ at time $t$ at speed $v_{p s}$, has acceleration $d v_{p s} / d t$, experiences force of resistance to motion $F_{r r}$, gravitational force from the slope of the track $F_{g}$, as well as force of resistance from motion in the curves $F_{c}$ and at the same time traction motors provide the traction or braking force $F_{t}$, then the relationship of the distance traveled by the train and the speed with time, as well as with the forces acting on it, is represented in the form of a system

$$
\left\{\begin{array}{l}
\frac{d v_{p s}}{d t}=\frac{ \pm F_{t}-F_{r r} \pm F_{g}-F_{c}}{(1+\varepsilon) m_{p s}} \\
\frac{d s}{d t}=v_{p s} .
\end{array}\right.
$$

where $(1+\varepsilon)$ is the coefficient of the rotating mass of the train.

The resistance to motion due to the rolling friction of the wheels on the rails and the aerodynamics of the train is determined using the Davis formula

$$
F_{r r}=A_{r r}+B_{r r} v_{p s}+C_{r r} v_{p s}^{2},
$$

where $A_{r r}, B_{r r}, C_{r r}$ are the constant coefficients depending on the configuration of the train.

These coefficients are due to the following: $A_{r r}-$ rolling friction of wheels on rails and friction of axles of wheel pairs; $B_{r r}$ - friction of the wheel flanges against the side surfaces of the rail head; $C_{r r}$ - train aerodynamics.

The gravitational force from the slope is calculated using the equality:

$$
F_{g}=0,001 m_{p s} g i,
$$

where $g \mathrm{~s}$ the acceleration of gravity; $i$ is the slope of the track.

The drag force from movement in curves for trains of the class under consideration is determined using the expression

$$
F_{c}=\frac{0,006867}{R} m_{p s},
$$

where $R$ is the curve radius.

Thus, the presented model shows that for given track parameters and restrictions on the speed of rolling stock on its sections, the curves of movement are determined by the power on the rim of the wheels $P_{w r}$. By varying $P_{w r}$ by changing its constituent components, it is possible to regulate the required traction force and the speed of the rolling stock.

\section{Mathematical model of the traction block.}

By the traction block we denote a part of the traction electric drive circuit, including FESS and DM, which, through the S_DC-DC and TI converters, respectively, are fed by the so-called traction current $I_{p}$, which is formed by the FC current $I_{d c}$ minus the current of auxiliary consumers $I_{a s}$

$$
I_{p}=\frac{U_{f c} I_{f c} \eta_{p \_} d c}{U_{c d}}-I_{a s},
$$

where $\eta_{p d c}$ is the efficiency of the P_DC-DC.

At this stage of research, this current will be considered given and unchanged. This assumption implies the exchange of energy only within the traction block, that is, between the DM actuator and the FESS storage device, and the operation of the P_DC-DC converter in a static mode with a specific conversion factor.

The central link of the traction block is an inertial energy storage device. FESS is a combination of an annular cylindrical flywheel (accumulator) and a SEMEC electromechanical energy converter system in the form of a inverted DC machine with excitation from permanent magnets and a semiconductor switch [12,13].

The SEMEC diagram is shown in Fig. 3. Here we are dealing with a two-pole four-phase machine, each phase of which contains one coil, displaced along the circumference of the armature by an angle proportional to $\tau / N_{f}$, where $N_{f}$ is the number of phases, and $\tau$ is the pole division.

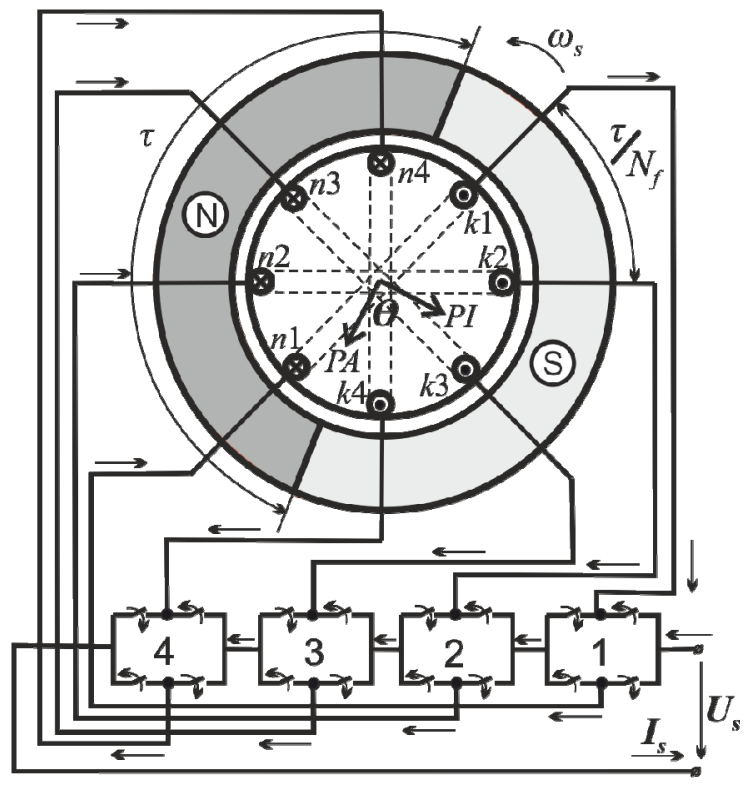

Fig. 3. System for electromechanical energy conversion of storage device:

$\theta$-load angle between the axis of the magnetic field of the inductor $P I$ and the armature current $P A ; n 1 \ldots n 4, k 1 \ldots k 4-$

beginnings and ends of the winding coils, respectively; $1 . . .4$ - switches

Mathematical models of the operation of the traction block in acceleration and braking modes are presented in Table 1.

As follows from the formula for the EMF of the drive of the SEMEC (Table 1), in the system under 
consideration it is possible to regulate the value of the electromotive force in two channels - by the number of phases of the armature winding and by the load angle, changing the switching algorithm of semiconductor switches. Thus, during the exchange of energy of the storage device and the link of electromechanical energy conversion, it is possible to influence both the power of the process and its components within wide ranges.

The meaning of the symbols in expressions presented in Table 1 is the following: $\eta_{s}, e_{s}, L_{s}, R_{s}-$ the efficiency, the EMF, the inductance and the active resistance of the storage device armature winding, respectively; $2 p, w_{s}, l_{a}, a-$ the number of poles, the number of turns per phase, the active length and the number of parallel branches of the storage device SEMEC armature winding, respectively; $D_{a}-$ the armature diameter; $B_{s r}-$ the average value of the magnetic flux density in the gap; $\eta_{\text {sum }}=\eta_{g} \eta_{m} \eta_{i n v} \eta_{s_{-} d c} \eta_{s}$ - the overall efficiency of the transmission; $f_{r r}$ - the specific value of resistance to movement; $L_{s_{-} d c}, R_{s_{-} d c}-$ the inductance and active resistance of the converter, respectively; $K_{c h T}, K_{c h B}$ - the conversion factors in acceleration and braking modes, respectively.

Table 1

Traction block mathematical model [14]

\begin{tabular}{|c|c|}
\hline Acceleration mode & Braking mode \\
\hline \multicolumn{2}{|c|}{ Storage device power balance } \\
\hline$-J_{s} \frac{d \omega_{s}}{d t} \omega_{s} \eta_{s}=u_{s} i_{s}$ & $J_{s} \frac{d \omega_{s}}{d t} \omega_{s}=u_{s} i_{s} \eta_{s}$ \\
\hline \multicolumn{2}{|c|}{ Equilibrium equation for voltage on the SEMEC } \\
\hline$u_{s}=e_{s}-L_{s} \frac{d i_{S}}{d t}-i_{s} R_{s}$ & $u_{s}=e_{s}+L_{s} \frac{d i_{s}}{d t}+i_{s} R_{s}$ \\
\hline \multicolumn{2}{|c|}{ Power developed by the rolling stock } \\
\hline$\left(m_{p s} \frac{d v_{p s}}{d t}-F_{r r}\right) v_{p s}=u_{d c} i_{i n v} \eta_{i n v} \eta_{m} \eta_{g}$ & $-\left(m_{p s} \frac{d v_{p s}}{d t}-F_{r r}\right) v_{p s} \eta_{i n v} \eta_{m} \eta_{g}=u_{d c} i_{i n v}$ \\
\hline \multicolumn{2}{|c|}{ EMF of the storage device SEMEC } \\
\hline \multicolumn{2}{|c|}{$\begin{array}{c}e_{s}=K_{e} \omega_{s} \\
K_{e}=\frac{2 p w_{s} N_{f} l_{a} D_{a}}{a} \sin \theta \cdot B_{s r}\end{array}$} \\
\hline \multicolumn{2}{|c|}{ DC link current } \\
\hline $\begin{array}{c}K_{c h T}=\frac{U_{d c}}{U_{s}} \\
i_{i n v}=i_{c h}+i_{p}=\frac{i_{s} \eta_{s_{-} d c}}{K_{c h T}}+i_{p}\end{array}$ & $\begin{array}{c}K_{c h B}=\frac{U_{s}}{U_{d c}} \\
i_{\text {inv }}=i_{c h}-i_{p}=\frac{i_{s} K_{c h B}}{\eta_{s_{-} d c}}-i_{p}\end{array}$ \\
\hline \multicolumn{2}{|c|}{ Mathematical model of the energy conversion process } \\
\hline $\begin{array}{l}\frac{d v_{p s}}{d t}=\frac{\eta_{i n v} \eta_{m} \eta_{g} u_{d c}\left(i_{s} \eta_{s_{-} d c} / K_{c h T}+i_{p}\right)}{m_{p s} v_{p s}}+f_{r r} \\
\frac{d i_{s}}{d t}=\frac{K_{e} \omega_{s}-u_{d c} / K_{c h T}-i_{s}\left(R_{s}+R_{s_{-} d c}\right)}{L_{S}+L_{s_{-} d c}} \\
-\frac{d \omega_{s}}{d t}=\frac{1}{J_{s} \eta_{s}} K_{e} i_{s}\end{array}$ & $\left\{\begin{array}{l}\frac{d v_{p s}}{d t}=-\frac{u_{d c}\left(i_{s} \eta_{s_{-} d c} / K_{c h B}-i_{p}\right)}{\eta_{i n v} \eta_{m} \eta_{g} m_{p s} v_{p s}}-f_{r r} \\
\frac{d i_{s}}{d t}=\frac{u_{d c} / K_{c h B}-K_{e} \omega_{s}-i_{s}\left(R_{s}+R_{s_{-} d c}\right)}{L_{S}+L_{s_{-} d c}} \\
\frac{d \omega_{s}}{d t}=\frac{\eta_{s}}{J_{s}} K_{e} i_{s}\end{array}\right.$ \\
\hline \multicolumn{2}{|c|}{ The relationship between the rotational speed of the storage device rotor and the speed of the rolling stock } \\
\hline$\omega_{s(k+1)}=\sqrt{\omega_{s k}-\frac{m_{p s}\left(v_{\left.p s(k+1)-v_{p s k}^{2}\right)}^{J_{s} \eta_{s u m}}\right.}{}}$ & $\omega_{s(k+1)}=\sqrt{\omega_{s k}+\frac{m_{p s} \eta_{s u m}\left(v_{p s k}^{2}-v_{p s(k+1)}^{2}\right)}{J_{s}}}$ \\
\hline
\end{tabular}

It is important to note that the model includes two adjustable components - the storage device SEMEC EMF $\left(K_{e}\right)$ and the DC link current $\left(K_{c h}\right)$, the impact on which provides a controlled power flow between the components of the traction block circuit.
The control of the process of power exchange in the modes of acceleration and braking of the rolling stock is implemented in software in accordance with the diagram shown in Fig. 4 (braking mode), based on logic gates [14]. 
The control block (CB) implements the following functions:

$$
\begin{aligned}
& f_{c h}\left(T_{\text {set }}, v_{p s}\right)=K_{\text {ch } 0}+\left(K_{p s c h} / T_{\text {set }}\right) v_{p s}, \\
& f_{e}\left(T_{\text {set }}, v_{p s}\right)=K_{e 0} v_{p s}^{2}+\left(K_{p s e} / T_{\text {set }}\right) v_{p s} .
\end{aligned}
$$

In this case, the following conditions are met.

For braking mode:

1. If the inverter current $i_{i n v} \in\left[i_{\min } ; i_{\max }\right]$, then $K_{c h}=f_{c h}\left(T_{s e t}, v_{p s}\right), K_{e}=f_{e}\left(T_{s e t}, v_{p s}\right)$.

2. If $i_{\text {inv }}>i_{\max }$, then $K_{c h}=K_{c h \text { max }}, K_{e}=K_{e \max }$.

3. If $i_{\text {inv }}<i_{\min }$, then $K_{c h}=K_{c h \min }, K_{e}=f_{e}\left(T_{s e t}, v_{p s}\right) / 4$.

For acceleration mode:

1. If the inverter current $i_{i n v} \in\left[i_{\min } ; i_{\max }\right]$, then $K_{c h}=f_{c h}\left(T_{s e t}, v_{p s}\right), K_{e}=f_{e}\left(T_{s e t}, v_{p s}\right)$.

2. If $i_{\text {inv }}>i_{\max }$, then $K_{c h}=K_{c h \text { min }}, K_{e}=f_{e}\left(T_{s e t}, v_{p s}\right) / 4$.

3. If $i_{\text {inv }}<i_{\min }$, then $K_{c h}=K_{c h \max }, K_{e}=K_{e \max }$.

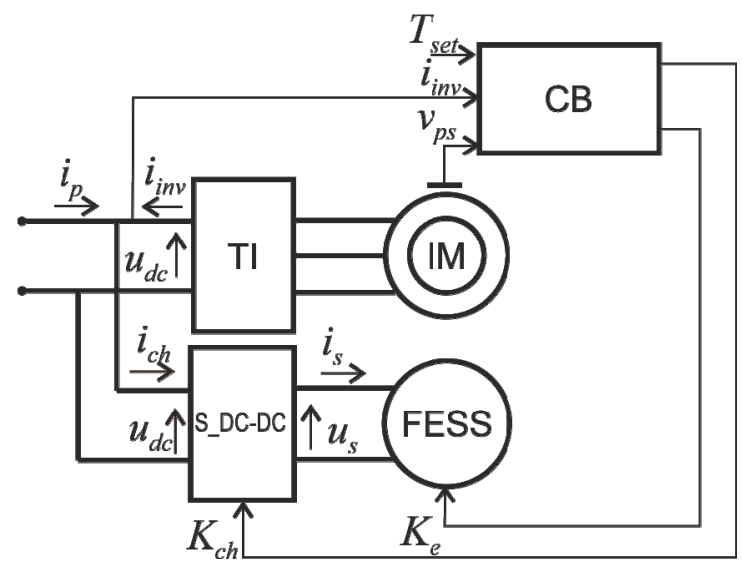

Fig. 4. Control system

To assess the properties of the storage device operation in the traction electric drive system, the efficiency factor of the storage device was proposed [14]:

$$
K_{e f s}=\frac{J_{s}\left(\omega_{s e n d}^{2}-\omega_{s d v}^{2}\right)}{m_{p s}\left(v_{p s s t B}^{2}+v_{p s e n d T}^{2}\right)},
$$

where $v_{p s s t B}$ is the rolling stock speed at the start of braking; $v_{\text {psendT }}$ is the rolling stock speed at the end of acceleration; $\omega_{\text {send }}$ is the storage device rotor rotation frequency at the end of recuperation; $\omega_{s d v}$ is the rotation frequency of «dead volume».

Thus, a mathematical model of the traction block is obtained, which connects the process of train movement in modes of acceleration as well as regenerative braking, with the parameters of an inertial energy storage device, characteristics of a traction motor and converters of a traction electric drive. The control system formed on the basis of logical elements programmatically implements power flows in the considered operating modes of the rolling stock between the traction motors, the storage device and the battery of fuel cells (currents $i_{i n v}, i_{c h}, i_{p}$, respectively). A criterion for assessment of the efficiency of using the technology under consideration is proposed.

\section{Mathematical model of the fuel cell.}

The mathematical model of the fuel cell (FC) is clear from the diagram shown in Fig. 2. The main electrical characteristics of the fuel cell are: EMF $E_{f \mathrm{c}}$, output voltage $U_{f c}$, internal electrical resistance $R_{f c}$, electrical power $P_{f c}$, electrical efficiency $\eta_{E}[16,17]$.

The power transmitted to the external load (useful power) is equal to:

$$
P_{f_{c}}=U_{f_{c}} I_{f_{c}}=I_{f_{c}} E_{f_{c}}-I_{f c}^{2} R_{f_{c}} .
$$

Electrical power dissipated on the internal resistance:

$$
P_{f_{c i}}=\left(E_{f_{c}}-U_{f_{c}}\right) I_{f_{c}}=\frac{\left(E_{f_{c}}-U_{f_{c}}\right)^{2}}{R_{f c}}=I_{f_{c}}^{2} R_{f_{c}} .
$$

In the above interpretation of powers, the electrical efficiency is will be equal to:

$$
\eta_{E}=\frac{P_{f_{c}}}{P_{f_{c i}}+P_{f_{c}}}=\frac{U_{f_{c}}}{E_{f_{c}}} .
$$

Information about the fuel cell and the clarity of its perception is contained in its volt-current plot (VCP). It is a graphical plot of fuel cell voltage versus load current. In most cases, the VCP of solid oxide fuel cells is a straight line. Strictly speaking, the initial and final sections of the VCP have deviations from a straight line, respectively, up and down (due to the electrochemical polarization of the electrodes for the final section). In most cases, these deviations are insignificant and practically do not go beyond 10-15\% of the beginning and end of the VCP curve section, and in some cases they are not observed at all. The middle section of the VCP is more important. Here, with some approximation, it can be assumed that the point of intersection of the VCP line with the voltage axis characterizes the EMF of the element, and the point of intersection of the VCP with the current axis characterizes the short circuit current of the element. The $\mathrm{VCP}$ is well approximated by a first order polynomial

$$
\begin{gathered}
y=-k x+b, \\
U_{f c}=-I_{f c} R_{f c}+E_{f c},
\end{gathered}
$$

where $y$ and $x$ are the coordinates of voltage and current; $k$ is the slope equal to tangent $\alpha$ - the angle of inclination of the VCP line to the current axis; $b$ is the value of the segment that cuts off the VCP line on the voltage axis (in our case, $b$ is equal to $E_{f c}$ of the element).

\section{Conceptual design.}

The task of developing a conceptual design is to select the parameters of a traction block, an inertial energy storage device and a fuel cell battery (in conjunction with a hydrogen storage cell) by solving the traction problem and analyzing the results obtained. Converting units (P_DC-DC, S_DC-DC, TI) will be considered only from the standpoint of the possibility of providing with their help the required energy flows between the blocks under consideration. It is obvious that their efficient operation will take place provided that the nominal values of the power components of the devices under consideration are as close as possible. With the unconditional observance of the power balance and based on the fact that the mentioned units of the traction drive in the DC link are connected in parallel, we believe that the voltage values of these units should be as close as possible. Fulfillment of this condition, in our opinion, 
will become the basis for effective regulation of power flows in various modes of operation of electric rolling stock (ERS).

When choosing the parameters of the traction drive units, we will proceed from the fact that the powers of the fuel cell block and the energy storage device are practically the same and the storage device operates only during acceleration and braking of the train, and in the mode of movement at a steady speed, the system is supplied with energy only from the fuel cell battery.

For calculation we take: train length is $42 \mathrm{~m}$, composition -2 cars, tare weight is 92 tons, car passenger capacity - 280 people, car bodies rest on 3 bogies - two end biaxial and one intermediate biaxial Jacobs bogie, design speed is $124 \mathrm{~km} / \mathrm{h}$. Basic resistance to movement is calculated by the formula $F_{r r}=1,5+0,006 v_{p s}+0,0067 v_{p s}^{2}$. The inner axles of the end bogies are equipped with traction motors. The wheel-motor unit of each of these axles contains a wheelset with a wheel diameter of $0.95 \mathrm{~m}$, a two-stage gearbox with a gear ratio of 6.6 and efficiency 0.97 as well as a six-pole induction traction motor. The train has two identical traction drive systems located in each carriage. Each includes a hydrogen storage cell, a block of fuel cells, an inertial energy storage, a traction motor and conversion units.

The characteristics of the motor and the parameters of the drive are given in Table 2, 3, respectively.

Table 2

Traction motor characteristics

\begin{tabular}{|c|c|c|c|c|c|c|c|}
\hline $\begin{array}{c}P_{m}, \\
\mathrm{~kW}\end{array}$ & $\begin{array}{c}U_{m}, \\
\mathrm{~V}\end{array}$ & $\begin{array}{c}I_{m}, \\
\mathrm{~A}\end{array}$ & $\cos \varphi_{m}$ & efficiency & $S, \%$ & $\begin{array}{l}f_{1}, \\
\mathrm{~Hz}\end{array}$ & $\begin{array}{c}n, \\
\mathrm{rpm}\end{array}$ \\
\hline 250 & 760 & 228 & 0,88 & 0,944 & 1,3 & 65 & 1283 \\
\hline
\end{tabular}

Table 3

Storage device parameters

\begin{tabular}{|l|c|}
\hline \multicolumn{1}{|c|}{ Parameter } & Value \\
\hline Dimensions, mm: $D \times H$ & $900 \times 830$ \\
\hline Energy of exchange, MJ & 26 \\
\hline Power (maximum), MW & 0,27 \\
\hline Voltage (maximum), V & 1054 \\
\hline Nominal current, A & 250 \\
\hline \multicolumn{2}{|c|}{ Flywheel } \\
\hline Material Armature & Carbon fiber + SmCo \\
\hline $\begin{array}{l}\text { Dimensions, mm: outer diameter } \times \\
\text { inner diameter } \times \text { height }\end{array}$ & $700 \times 440 \times 580$ \\
\hline Mass, kg & 674 \\
\hline Moment of inertia, $\mathrm{kg} \cdot \mathrm{m}^{2}$ & 57 \\
\hline Rotation frequency, $1 / \mathrm{s}:$ max...min & 4 \\
\hline \multicolumn{2}{|c|}{ Inductor } \\
\hline Number of poles & 340 \\
\hline Pole division, mm & 421 \\
\hline Number of phases & 50 \\
\hline Conductor cross section, mm ${ }^{2}$ & $340 \times 420 \times 15$ \\
\hline & 0,22 \\
\hline $\begin{array}{l}\text { Magnet dimensions, mm: length } \times \\
\text { height } \times \text { width }\end{array}$ & 3 \\
\hline $\begin{array}{l}\text { Magnetic flux density in the active } \\
\text { zone, T }\end{array}$ & \\
\hline Gap, mm & \\
\hline
\end{tabular}

The movement curves, power and energy dependencies obtained for this train during its movement along a horizontal track section $24.3 \mathrm{~km}$ long show that the power of the power source in the form of fuel cells, as well as an inertial storage device per one car, must be at least $260 \mathrm{~kW}$. The flywheel of each inertial energy storage device must accumulate exchange energy of at least $7.25 \mathrm{kWh}$ during braking (the regenerative braking energy is $14.49 \mathrm{kWh}$ ).

Calculation and study of the operation of the traction block with the control system (Fig. 4) with the values of the parameters of the control block given in Table 4 were carried out on the basis of a mathematical model (Table 1). The fourth-order Runge-Kutta method was chosen as a numerical method for solving a system of differential equations. The calculation was carried out for three acceleration values $-0.55 \mathrm{~m} / \mathrm{s}^{2}, 0.37 \mathrm{~m} / \mathrm{s}^{2}$ and $0.28 \mathrm{~m} / \mathrm{s}^{2}$. The calculation results are shown in Fig. 5 .

Table 4

Control block parameter values

\begin{tabular}{|c|c|c|c|c|c|}
\hline Parameter & Value & Parameter & Value & Parameter & Value \\
\hline$K_{c h 0}$ & 0,1 & $\begin{array}{c}K_{p s e,} \\
\mathrm{~s}^{2} / \mathrm{m}\end{array}$ & 7,3 & $K_{c h \min }$ & 0,1 \\
\hline $\begin{array}{c}K_{p s c h}, \\
\mathrm{~s}^{2} / \mathrm{m}\end{array}$ & 3,9 & $i_{\min }, \mathrm{A}$ & 360 & $K_{c h \max }$ & 4 \\
\hline $\begin{array}{c}K_{e 0}, \\
\mathrm{~s}^{2} / \mathrm{m}\end{array}$ & 0,05 & $i_{\max }, \mathrm{A}$ & 440 & $K_{e \max }$ & 7,3 \\
\hline
\end{tabular}

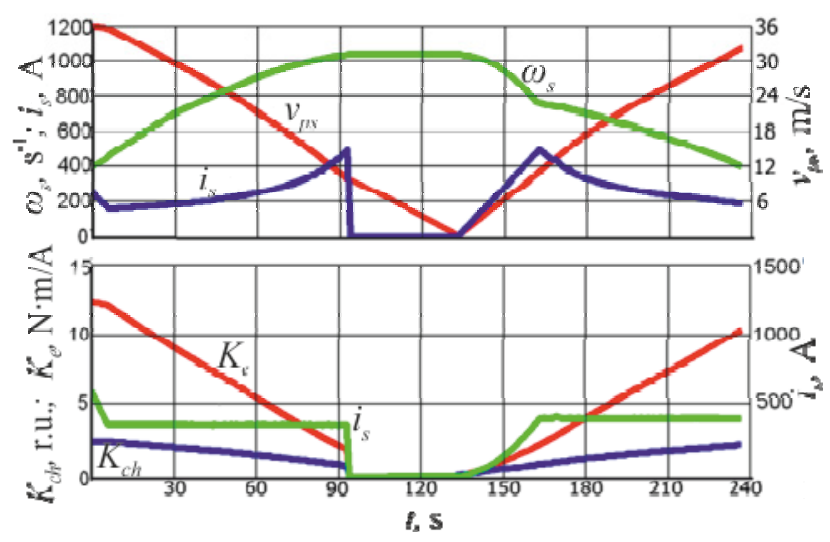

Fig. 5. Energy exchange process at acceleration of $0.55 \mathrm{~m} / \mathrm{s}^{2}$

The analysis of the calculation results showed that the efficiency of using the energy storage at variable accelerations in the range of $0.55-0.28 \mathrm{~m} / \mathrm{s}^{2}$ is $28-37 \%$. Thus, the use of the storage device makes it possible to save about $40 \%$ of energy in one cycle «brakingacceleration».

For the train in question, the HyPM ${ }^{\mathrm{TM}} \mathrm{HD} 30$ fuel cell blocks are most suitable. Block power is $31 \mathrm{~kW}$, current is $0-500 \mathrm{~A}$, voltage is $60-120 \mathrm{~V}$, maximum efficiency is 55 $\%$, dimensions are $719 \times 406 \times 261 \mathrm{~mm}$, mass is $72 \mathrm{~kg}$. The performance characteristics are shown in Fig. 6 [15].

9 such blocks, connected in series, on each carriage will provide source power of $280 \mathrm{~kW}$ in the voltage range of 540-1080 $\mathrm{V}$ when the load changes from 0 to $500 \mathrm{~A}$. Such a battery, located in a container measuring $2.2 \times 1.5 \times 0.4 \mathrm{~m}$, will weigh $650 \mathrm{~kg}$, and can be placed on the roof of the car without any problems. 


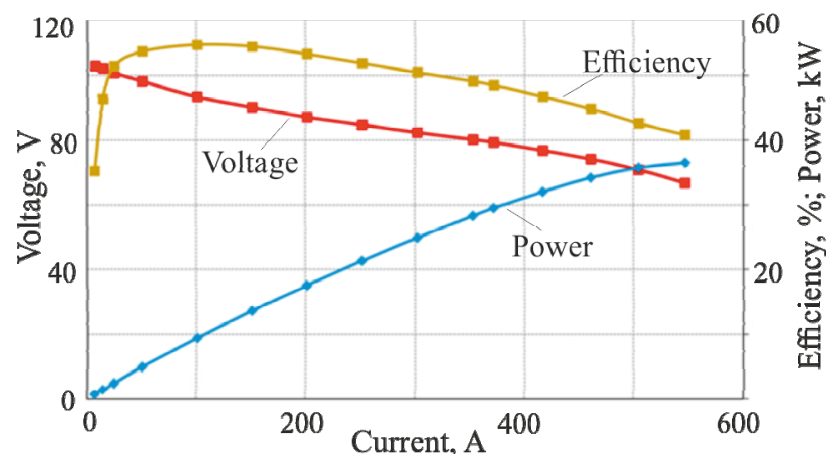

Fig. 6. Performance characteristics of the block $\mathrm{HyPM}^{\mathrm{TM}} \mathrm{HD} 30$

The necessary demand for hydrogen when the rolling stock is moving without a storage device in acceleration and driving modes with constant power is determined by the formula

$$
M_{H}=\frac{E_{H f c}-E_{H s}}{E_{H s p} \eta_{E}},
$$

where $E_{H f c}$ is the electrical energy of the fuel cell battery; $E_{H s}$ is the energy of recuperation during braking and its subsequent use during acceleration; $E_{H s p}$ is the specific weight energy index of hydrogen fuel.

For our case, at $E_{H f c}=396 \mathrm{MJ}, E_{H s}=63 \mathrm{MJ}$, $E_{H s p}=120 \mathrm{MJ} / \mathrm{kg}$ and $\eta_{E}=0.55$, the hydrogen consumption per one transport cycle will be $3.9 \mathrm{~kg}$ when operating without a storage device, and $3 \mathrm{~kg}$ with a storage device.

With the capacity of the currently used tanks with a pressure of $35 \mathrm{MPa}$ and a mass of hydrogen of $5 \mathrm{~kg}$ [16], 6 such tanks with a mass of $\approx 700 \mathrm{~kg}$ and an occupied volume of $2.86 \mathrm{~m}^{3}$ will ensure the movement $188 \mathrm{~km}$ of the train in question in the absence of a storage device without refueling. If the drive is storage device, the mileage will be $250 \mathrm{~km}$ without refueling.

Thus, the use of the storage device with its one-time use in the simplest transport cycle without taking into account the rational ratios of the parameters of the control block gives a rather tangible effect - saving at least $24.5 \%$ of hydrogen.

\section{Conclusions and prospects for further development.}

The studies were carried out on the basis of a mathematical model of a traction electric drive of a train on fuel cells with an inertial energy storage, which is a set of separate blocks of differential and algebraic equations for a train and various blocks of a traction electric drive circuit. This model should be considered as basic. To study the behaviour of rolling stock in conditions close to real ones, it is necessary, on the basis of the developed mathematical models, to create a unified system of differential equations, with the help of which to couple the operation of all blocks of the traction electric drive system, including the operation of converting units of semiconductor devices, with the coordinates of the track both in time and in space.

The solution of such a problem will undoubtedly require the creation of a unified three-level intelligent control system.
The first level should determine the power required by the train, control the speed of the vehicle and transfer the required acceleration or deceleration to the second and third levels.

The second level should control the distribution of power and energy flows between various components of the traction chain: a fuel cell battery, an energy storage device and an actuator - a traction induction motor.

The third level should act on the controls of individual components and adjust their state depending on the power generated or consumed by these components.

Conflict of interest. The authors declare that they have no conflicts of interest.

\section{REFERENCES}

1. Thorne R., Amundsen A.H., Sundvor I. Battery electric and fuel cell trains: maturity of technology and market status. Report 1737/2019. Institute of Transport Economics, 2020. 32p. Available at: https://www.toi.no/getfile.php?mmfileid=52027 (accessed 22 March 2021).

2. Hoffrichter A., Hillmansen S., Roberts C. Conceptual propulsion system design for a hydrogen-powered regional train. IET Electrical Systems in Transportation, 2016, vol. 6, no. 2, pp. 56-66. doi: https://doi.org/10.1049/iet-est.2014.0049.

3. Fender K. Development of hydrogen-powered trains continues, but battery-powered equipment making more inroads. December 14, $2020 . \quad$ Available at: https://www.trains.com/trn/news-reviews/news-

wire/development-of-hydrogen-powered-trains-continues-butbattery-powered-equipment-making-more-inroads (accessed 22 March 2021).

4. Furuta R., Kawasaki J., Kondo K. Hybrid traction technologies with energy storage devices for nonelectrified railway lines. IEEJ Transactions on Electrical and Electronic Engineering, 2010, vol. 5, no. 3, pp. 291-297. doi: https://doi.org/10.1002/tee.20532.

5. Ogawa K., Yamamoto T., Hasegawa H., Furuya T. Development of the fuel-cell/battery hybrid railway vehicle. 2009 IEEE Vehicle Power and Propulsion Conference, 2009, pp. 1730-1735. doi: https://doi.org/10.1109/vppc.2009.5289693.

6. Chen X., Shen W., Vo T.T., Cao Z., Kapoor A. An overview of lithium-ion batteries for electric vehicles. 2012 10th International Power \& Energy Conference (IPEC), 2012, pp. 230-235. doi: https://doi.org/10.1109/asscc.2012.6523269.

7. Baumann M., Peters J. F., Weil M., Grunwald A. $\mathrm{CO}_{2}$ footprint and life-cycle costs of electrochemical energy storage for stationary grid applications. Energy Technology, 2017, vol. 5, no. 7, pp. 1071-1083. doi: https://doi.org/10.1002/ente.201600622.

8. Liu X., Li K. Energy storage devices in electrified railway systems: A review. Transportation Safety and Environment, 2020, vol. 2, no. 3, pp. 183-201. doi: https://doi.org/10.1093/tse/tdaa016. 9. Hedlund M., Lundin J., De Santiago J., Abrahamsson J., Bernhoff H. Flywheel energy storage for automotive applications. Energies, 2015, vol. 8, no. 10, pp. 10636-10663. doi: https://doi.org/10.3390/en81010636.

10. Engel B., Söffker C., Hörl F. The innovative traction system with the flywheel of the Lirex ${ }^{T M}$. Available at: http://www.railway-research.org/IMG/pdf/457.pdf (accessed 22 March 2021).

11. Ogawa K., Yoneyama T., Sudo T., Kashiwagi T., Yamamoto T. Performance improvement of fuel cell hybrid powered test railway vehicle. Quarterly Report of RTRI, 2021, vol. 62, no. 1, pp. 16-21. doi: https://doi.org/10.2219/rtriqr.62.1_16. 
12. Omelyanenko V.I, Riabov Ie.S., Overianova L.V. Inertial energy storage device as an advanced energy conservation technology for electric rolling stock. Vestnik VELNII, 2013, no. 1 (65), pp. 38-54. (Rus).

13. Omelianenko H.V., Overianova L.V., Maslii A.S. Geometric and electrophysical parameters of armature winding of electromechanical converter of inertial energy storage for suburban trains. Electrical Engineering \& Electromechanics, 2020, no. 1, pp. 65-71. doi: https://doi.org/10.20998/2074272x.2020.1.11.

14. Severin V.P., Omelianenko O.V. Traction drive of electric train with inertial energy storage. Bulletin of the National Technical University «KhPI». Series: Problems of Automated Electrodrivs. Theory and Practice. Power Electronics and Energy Efficiency, 2017, no. 27 (1249), pp. 276-279. Available at: http://repository.kpi.kharkov.ua/bitstream/KhPI-

Press/33984/1/vestnik_KhPI_2017_27_Severin_Tyagovyy_privo d.pdf (accessed 22 March 2021). (Rus).

15. HyPM ${ }^{\mathrm{TM}} H D 30$ Heavy Duty Fuel Cell Power Module. Available https://pdf.directindustry.com/pdf/hydrogenics/hypm-hd30/33492-420319.html (accessed 22 March 2021).

How to cite this article:

Omelyanenko V.I., Riabov Ie.S., Overianova L.V., Omelianenko H.V. Traction electric drive based on fuel cell batteries and onboard inertial energy storage for multi unit train. Electrical Engineering \& Electromechanics, 2021, no. 4, pp. 64-72. doi: https://doi.org/10.20998/2074-272X.2021.4.08.
16. Ahluwalia R.K., Hua T.Q., Peng J.-K. Fuel cycle efficiencies of different automotive on-board hydrogen storage options. International Journal of Hydrogen Energy, 2007, vol. 32, no. 15, pp. 3592-3602. doi: https://doi.org/10.1016/j.ijhydene.2007.03.021.

Received 13.05.2021

Accepted 17.06.2021

Published 27.08.2021

V.I. Omelyanenko ${ }^{1}$, Doctor of Technical Science, Professor, Ie.S. Riabov ${ }^{1}, P h D$

L.V. Overianova ${ }^{1}, P h D$, Associate Professor,

H.V. Omelianenko ${ }^{1}$, PhD, Associate Professor,

${ }^{1}$ National Technical University «Kharkiv Polytechnic Institute», 2, Kyrpychova Str., Kharkiv, 61002, Ukraine, e-mail: vicel@ukr.net; riabov.ievgen@gmail.com; overanova@ukr.net (Corresponding author); omeljanenkgalina@i.ua 